This article was downloaded by: [New York University]

On: 13 April 2015, At: 14:05

Publisher: Routledge

Informa Ltd Registered in England and Wales Registered Number: 1072954

Registered office: Mortimer House, 37-41 Mortimer Street, London W1T

3J H, UK

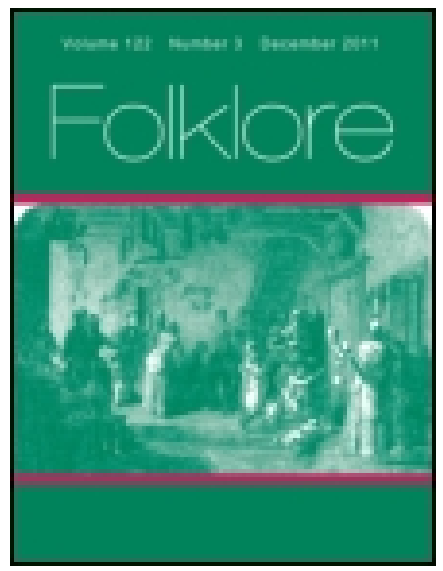

\title{
Folklore
}

Publication details, including instructions for authors and subscription information:

http:// www. tandfonline.com/loi/ rfol20

\section{Classified Catalogue of Brand Material.}

C. S. Burne

Published online: 01 Feb 2012.

To cite this article: C. S. Burne (1918) Classified Catalogue of Brand Material., Folklore, 29:2, 146-154, DOI: 10.1080/0015587X.1918.9719045

To link to this article: http:// dx. doi.org/ 10.1080/ 0015587X.1918.9719045

\section{PLEASE SCROLL DOWN FOR ARTICLE}

Taylor \& Francis makes every effort to ensure the accuracy of all the information (the "Content") contained in the publications on our platform. However, Taylor \& Francis, our agents, and our licensors make no representations or warranties whatsoever as to the accuracy, completeness, or suitability for any purpose of the Content. Any opinions and views expressed in this publication are the opinions and views of the authors, and are not the views of or endorsed by Taylor \& Francis. The accuracy of the Content should not be relied upon and should be independently verified with primary sources of information. Taylor and Francis shall not be liable for any losses, actions, claims, proceedings, demands, costs, expenses, damages, and other liabilities whatsoever or howsoever caused arising directly or indirectly in connection with, in relation to or arising out of the use of the Content.

This article may be used for research, teaching, and private study purposes. Any substantial or systematic reproduction, redistribution, reselling, loan, sub-licensing, systematic supply, or distribution in any form to anyone is 
expressly forbidden. Terms $\&$ Conditions of access and use can be found at http://www.tandfonline.com/page/terms-and-conditions 


\title{
CLASSIFIED CATALOGUE OF BRAND MATERIAL.
}

\author{
(Continued from Vol. $X X I X$. p. 74.)
}

(k) Strolling Visitors.

LOCALITY.

Waits (instrumental musicians : ' generally perform during night of Dec. 24-25).

Employed by municipality (obs.)

Licensed to solicit money within definite area (down to $1820-30$ )

- London Parishes.

Entirely independent; and lingered into Igth century Country towns (sporadic).

"Timbrel-waits" (tin-kettle music by boys, before Christmas)

- Wolverhampton, York-

" Bletherhead bands" (nigger minstrels) perambulate streets

Berwick, Scarboro:, Doncaster, Nottingham, Cambridge, Leicester, Chester, etc. shire towns.

Bradford.

Carol-singers (perform at housedoors, night or day, sometimes with instrumental accompaniment

- General.

Sing on church-tower - - Berks. (Newbury), Hants. (Crondall).

At holy wells - - - West Cornwall.

In Minstrels' Gallery - . Exeter Cathedral.

${ }^{1}$ But the name is often applied to singers, e,g. "The singing wails, a merry throng " (Clare, The Shepherd"s Kalendar). 
At choir-supper, Christmas Eve (Cf. Wassailing, above. $)^{2}$

Masqueraders.

Mummers (costumed figures, with blackened faces, enter unannounced, and sweep up hearth without speaking .

Hoodeners (carol-singers accompanied by a "hobbyhorse" "masquerader, extort money) - -

"The Broad" (wassailers accompanied by man personating bull, called the Broad) - - - -

"TheHorse'sHead orQueen's Pony" (Hobby-horse parody of the Doctor incident in the play of St. George) -

Sword-dancers (perform in character, introduced by song) Called Guizards -

Mummers' Play of St. George acted Performers called Guisers, Geese-dancers, Morrisdancers, Mummers, Tipteerers, etc. - - - In various counties.

(l) Games and Sports.

Boar-hunting, Christmas to

Candlemas - - Fox-hunting, Christmas to Lady

Day
West Riding.

Thanet and East Kent.
District between Pontefract and Doncaster.

Northumbria.

Co. Durham (Swalwell), Northumbd. (Earsdon), West Riding (Kirkby Malzeard, Grenoside, nr. Eccles. field, etc.).

General.

'It is desired to form a Bibliography of Christmas Carols. Information will be welcomed. 
LOC.ALITY.

Squirrel-hunting - - - Norfolk and Suffolk.

Bull-baiting - - - - Snffolk.

Butcher provided bull to be

killed by undergraduates Oxford.

"Cabsow" or "shin-up" (a kind of hockey) - - - Lincs. (Grimsby, Clee-

Quintain (medieval athletic sport). thorpes).

\section{Indoor Games.}

"Bite-apple" or " souseapple" (see November) - Lancs., Staffs., Salop.

Snap-dragon - - - General.

Carcl-playing - - - Universal.

Apprentices allowed to play carls at Christmas, $144^{6}$.

Children's gambling game with

pins -
Blindman's Buff, turn-the-tren-

Walsall.

Cornwall. cher, hunt the slipper, puss. in-the-corner, hot cockles, hide-and-seek (in various forms), Bobby Bingo, uranges and lemons, Buff, forfeits, memory games, etc., commonly played.

Christmas Tree introduced

Christmas Cards introduced

Christmas Pieces (children's specimens of caligraphy, disused)

Christmas Pantomimes introduced -

Circa 1789 .

I850-60.

Circa 1830.

T702, ut dicit.

1II. Local Observances.
(a) Bell-ringing Customs.
Christmas Eve.
Two bells rung, 4 p.m. "W . Wolverhampton.
"Cheese-and-bread bell," 7 p.m.
Peal rung, 8 p
"The Devil's Knell" (passing
bell) midnight -
- Wolverhampton.
- Yorkshire (general).
Yorkshire (Horsbury,
Dewsbury). 
LOCALITY.

Peal rung at midnight - - Beds, (Gt. Barford, Woburn), Herts. (Abbots' Langley, Ashwell, etc.),

Lincs. (Kirton in Lindsey, I640; cf. In Memoriam, No. xxviii. Staffs. (Bilston, I685, etc. : Wolverhampton, I 893).

Submerged bells thought to be heard at midnight - Salop (Bomere), Notts. (Raleigh).

\section{Christmas Day.}

Peals rung

"Pye bell," between noon and I p.m. - "

Beds, (Cranfield' Goldington, Flitwood), Glos. (Ruardlean, by bequest), Hants, (St. Mary Bourne ${ }^{3}$ ), Herts. (Rushden, King's Walden ${ }^{3}$ ), Lincs. (Edenham, S. Kelsey, etc.*), Rutland (" in most places"), Yorksh. (Wensleydale, called Virgin's Chimes).

"Plum-pudding bell" rung by request, a month before Christmas

Worcester (St. Helens).

Twelve days of Christmas, Curfew or "Culfer" rung on two bells, 7 a.m. and 7 p.m.

Leeds (I8th cent.).

Twelve days of Christmas, Curfew silent - . Worcester (St. Martins).
Salop (Cleobury Morti. mer).

' North, Ch, Bolls of Beds., p. 107.

3 "At Christmas the bells had no rest" (Stevens, st. Mary Bourne).

"North, Ch. Bells of Herts., p. 76.

"Ibid, Limis., ppo 220.221, "in very many places." 
150 Catalogue of Brand Material.

(b) Church-going Customs.

LOCALITY.

Christmas at Court (King George

II. escorted to Chapel Royal

by Heralds and Knights of

Garter, Thistle and Bath, communicated, and offered wedge of gold called Byzant) - -

Municipal Christmas, 1685 . hall and escorted Mayor to Church, on festival and its morrow) - - - -

Dancing in Church after service, crying "Yule, yule, yule!" -

Drinking together in alehouse after service ( $r 7_{\text {th }}$ cent.) *

Christmas Greetings in church-

yard before service - - Derbyshire villages.

(c) Customary Feasts.

Breakfast given by Bailiffs between Matins and High Mass on Christmas Day (discontinued (540) - - - -

Breakfast given by individual Aldermen, 1556 - - -

Breakfast for inhabitants on Christmas Day provided by monks, subsequently by farmer of parsonage - - - -

Ditto, by tithe-farmers, St.

Stephen's Day, i.e. 1800 - Oxon. (Bampton).

Rector provided bread, cheese and beer to inhabitants after afternoon service on Christmas Day

\section{$174 \mathrm{I}$.}

Newbury.

Berks.

North Yorksh. (I7th cent.).

Yorksh. (Danby Wiske).

Shrewsbury.

Chester.

Yarmouth.

Ditto, St. Stephen's Day -

Oxon. (Heyford), up to c. $173^{\circ}$

Bucks. (Drayton Beauchamp and Gt. Horwood).

Rectors remonstrated against similar custom, 1610, 1607 , 1765

Glos. (Evenley). 
Vicar gave beef, mustard, bread and cheese to all comers on Christmas Day, down to rgth cent.

Vicar provided bread, cheese, and beer for tithe-payers after evening service, to $\mathrm{I}^{814} 4$.

Ferryman remitted toll on Christmas Day and received loaf from parishioners; his dog fed at Vicarage .

Bread, ale, and mince-pies distributed to poor by Rector on old Christmas Day

Tenants-at-will made customary presents to Lord of Manor at Yule; he entertained them and their wives at dinner -

Feast in reeve's house : mincepies ; free drinks while candles burning. Associated with memory of King John - -

Break-up school-feast, cakes and sweet ale (Pegge) - - .

"Rumbald Whitings" (eight finest whitings from each boat - sold to provide supper for fishers, Christmas Eve - -

(d) Doles (cf. St. Thomas's Day).

Plums distributed to inhabitants Annuities to Widows, by bequest Beef, by bequest, $x 729$

(e) Other Customary Gifts.

Officers of King's Bench Court to Judges -

Tenants of Selby Abbey to Convent

Lord of Manor to Tenants, yule logs

Grocers gave plums to customers Lakers, a cake -
LOCALITY.

Staffs. (Gt. Barr and Aldridge).

Berks. (Cumnor).

Notts. (North Clifton).

Dorset (Piddlehinton).

Ashton-under-Lyne, 1422.

Somerset (North Curry).

Derbysh. (Whittington).

Folkestone.

Stafford (Forebridge).

Oxford (St. Thomas's)

Exeter (St. Mary Major).

See Roport of Royal Commission, 1820 .

Yorksh. (Selby, I 597).

Northumbd. (Belford), $1890-1900$

Northants., 1854 . 
Chandlers and grocers, Christmas candles -

Master joiners, yule-logs -

"Hardgrain," a presentof wheat or money made to children at Christmas

Stocking hung up to receive gifts

(f) Household Festivities.

Flouseholds of Nobility and Squirearchy (1 $7^{\text {th }}$ cent.). Tenantry assembled at daybreak; hospitality to all comers; servants dancing. masquerading. joined in games

Guessing identity masked fellow-servants, I795. Farmhouses (dances, collection for fiddler) . Cottages (" crusty loaf and mouldy cheese" ready for all comers)
LOCALITY.

Yorksh.

Yorksh.

Lancs. (Hund, of Lonsdale).

See Henderson, p. 67 .

\section{General (cf. Round about} our Coal Fire).

Aston, nr. Birmingham.

Somerset.

Derbyshive.

(g) Holidays, Merrymaking, etc.

Plough not worked (see Plough Monday).

Household work intermitted

Servants equalled masters

Servants leave places, Dec. 26; spend Christmas Weekathome

Fairs in Christmas Week.

Gauby Far (tormerly Hiring Fair)

Gauby Market (ditto) -

Giglet lair (a pleasure fair. introductions unnecessary ${ }^{1}$ )

South and West Salop.

Norfolk.

Cheshirc, North Staffs. North-east Salop.

"Merry Niglits" (subscription lances at public houses all

"Treating" expected from all comers, under pain of "stang. ricling " or "basketing"

Shrewsbury.

Salop (Newport).

Cornwall (Launceston). Devon (Okehampton).

Cumbd. and Westmd.

Ditto.

1 (X. Mistletoe. 
"Yule-girth" (immunity for bad characters during holidays) proclaimed - - - -

Watch and Ward kept three nights by Customary Tenants, $\mathbf{1 5 5 5 , 1 6 6 7 - \quad - \quad -}$

Yule-waiting or "yolwayting" by customary tenants (I 183 , compounded for money payment, I 4th cent.) - - Customary tenants watch twelve nights, turn and turn about - -

Ditto, 12 men and horses 12 nights, stick pins on leaving

Tenure of Breadsall by serving lord (Earl of Lancas. ter) at dinner and supper on Christmas Day

The Lord of Misrule (leader of Christmas revels, in royal, noble, and official households)

Styled Abbot of Misrule at court

Held office Hallowmas to Candlemas inclusive.

Styled "Christmas Prince" or " King of Christmas" -

Held office Flallowmas to Shrovetide

Fiected St. Edmund's Day (Nov. 19).

IKing's Lord of Misrule accompanied by masquerade procession visited city.

Dined with Lord Mayor and Sherifts

Dined at Templ

Stayed all night in Toultry Mayor kept open house I2 days. Lord of Misrule appointed, 1567
JOCAlATY

York.

Chester.

Durham.

St. Jaul's Cathedral.

Yorksh. (Wadsley).

Tutbury

London, Westminster, Greenwich, etc., Ioth century.

$I_{4} 89$.

Inns of Court.

St. John's College (Ox ford).

I $5.5 \mathrm{I}$, etc.

r56r.

New Year's Eve, 1557-8.

Chester. 


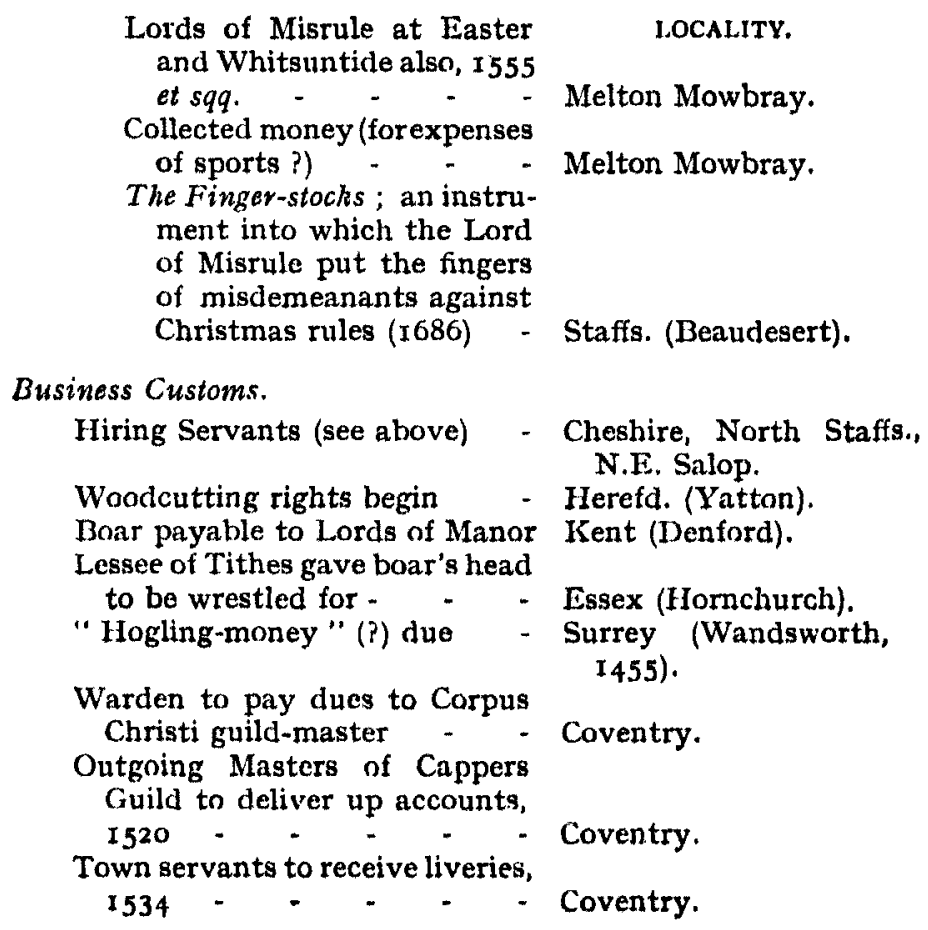

(To be continued.) 